\title{
The REDD+ policy arena in Vietnam: participation of policy actors
}

\author{
$\underline{\text { Thuy T. Pham }}^{1}, \underline{\text { Monica Di Gregorio }}^{2}, \underline{\text { Rachel Carmenta }}^{1}, \underline{\text { Maria Brockhaus }}^{1}$ and Dung N. Le ${ }^{1}$
}

\begin{abstract}
Reducing emissions from deforestation and degradation (REDD+) has gained increasing global attention because of its potential to reduce carbon emissions and improve forest governance. Reducing emissions from deforestation and degradation requires successful inclusive decision making and accountability. However, there have been limited empirical studies that examine the effectiveness of the current participatory mechanism used in REDD+. Our research analyzes the participation of policy actors in the development of the REDD+ instrument in Vietnam. We are interested in how the political context and the different interests of actors influence the degree of participation in national REDD+ policy decision making. We explored participation through the analysis of the mechanisms, e.g., how actors involve and participate in decision making, and dynamics of participation, e.g., highly centralized policy event vs. donor led event. The study aims to answer three research questions: (1) Who is involved in national REDD+ policy making and what are their interests in participating in core political events? (2) What level of participation do the different political actors have in core political events? and (3) To what extent do the outcomes, e.g., regulations and strategies, of REDD+ policy events incorporate different preferences of policy actors? Our findings highlighted the dominant role of government agencies in REDD+ policy making, which leaves limited political space for nonstate actors, e.g., NGOs and civil society organizations (CSOs), in Vietnam to exert an influence on the final policy outputs. Even in this highly centralized context, however, we found evidence to suggest that some political space in decision making is given to nonstate actors. Within this space, such actors are able to propose alternative policy options. Ensuring inclusive decision making and accountability in the Vietnam context requires a shift in current governance from traditional top-down approaches to a more participatory form of decision making.
\end{abstract}

Key Words: inclusion; participation; policy networks; REDD+; Vietnam

\section{INTRODUCTION}

Reducing emissions from deforestation and forest degradation (REDD+) refers to a series of objectives designed to use market and financial incentives to alter the behavior of landholders and forest users with the result of reducing emissions of greenhouse gases from deforestation and forest degradation and enhancing carbon stocks (Groom and Palmer 2012). The REDD+ objectives are expected not only to reduce emissions, but also to improve forest governance (Sikor 2010) through national safeguards, which help to ensure accountability, participation, transparency, and legitimacy in resource governance (Phelps et al. 2010, UNFCCC 2010, Murphy 2011, Chaskin et al. 2012, McDermott et al. 2012, Visseren-Hamakers et al. 2012).

Participation in decision making has received particular attention in the literature because REDD+ affects multiple actors, e.g., smallholders to agroindustry, whose interests, which range from achieving carbon effectiveness to ensuring equity at the local level through recognition of forest people's rights, will need to be addressed with a single instrument (Angelsen 2008, Hayes and Persha 2010, Sikor 2010, Larson 2011, Chhatre et al. 2012, Mustalahti et al. 2012, Bourgoin et al. 2013). Numerous attempts have been made to define participation, which is notoriously complex (Arnstein 1969, Pretty 1995, Hayward et al. 2004, Stringer et al. 2006, Cornwall 2008, Shortall 2008, Quick and Feldman 2011).

Our research aimed to reveal the extent to which REDD+ policy formulation in Vietnam incorporates a participatory approach. We view participation as actors' power and ability to influence and make changes during all stages of policy development, implementation, and evaluation. We also take into account VeneKlasen and Miller's (2002) framework, which states that the goal of participation should not only be about having an impact on policy decisions, but also about educating people about their rights and how the political process works. Vietnam is an interesting case study for such analysis because it is one of the very few countries that has retained a strong socialist political regime (Pham et al. 2012). Institutions within Vietnam's forestry sector are heavily influenced by the political legacy of centralized, i.e., nonparticipatory, decision making (de Jong et al. 2006). This has led to increasing concern among stakeholders that REDD+ in Vietnam could be threatened by under-representation and weak participation of nonstate political actors in policy processes (Pham et al. 2012).

We addressed the following questions: (1) Who is involved in national REDD+ policy making, and what are their interests in participating in core political events? (2) What level of participation do different political actors have in the core policy events? and (3) To what extent do the outcomes, e.g., regulations, decrees, of $\mathrm{REDD}+$ policy events incorporate the preferences of policy actors?

\section{ANALYTICAL FRAMEWORK}

Forest management involves various actors in various sectors, e.g., forestry, agriculture, mining, etc., whose interests in the outcomes of decision making often diverge (Brechin et al. 2003, Raik and Decker 2007). A key consideration in forest governance, therefore, is the level of participation of these different policy actors (Larson 2011). Governing with multiple actors creates a challenge for REDD+ because rules are designed and interpreted at multiple scales (Corbera and Schroeder 2011, Thompson et al. 2011, McDermott et al. 2012). We analyzed the participation of actor groups through the following research questions.

(1) Who is involved in national REDD+ policy making, and what are their interests in participating in core political events? An actor's presence in decision making is crucial. If an actor is not present, then the decisions are unlikely to take into account their concerns (Phillips 1995). Who is included in decision making and who is 
intentionally or unintentionally excluded have been identified as central questions, which studies of REDD+ must address to understand the legitimacy of decision making (Cornwall 2008, Shortall 2008, Thompson et al. 2011, McDermott 2012). Such attempts can help to advise trajectories to ensure the meaningful participation of stakeholders and to generate legitimacy for REDD+ interventions (Lederer 2011, Lyster 2011). Effective public participation requires participatory processes, i.e., an approach that seeks to engage all stakeholders in guiding and shaping new policy development and secures a lasting commitment and strong sense of ownership of all actors, that can accommodate different actors' opinions, preferences, and values (Hampton 2004) and different levels of desire to engage in decision making (Fiorina 1999, Vatn and Vedeld 2013). Understanding interests in various forms of participation is important because it can clarify why or how participation occurs or does not occur at any particular stage in the policy process (White 1996, Cornwall 2008, Black-Hawkins 2010). Vietnam's national REDD+ program requires the participation of all actors who are involved in or affected by forest management, whether state or nonstate (Government of Vietnam 2012). Therefore, it is important to analyze the degree to which REDD+ policy making in Vietnam is inclusive and to assess whether all actors or affected parties and their interests are represented in REDD+ policy events.

(2) What level of participation do different political actors have in key national REDD+ policy events? The presence of an actor group at a policy event is not enough to explain the process and dynamics of participation (Marochi 2010). Even more important than understanding who is present in decision making is understanding how they influence the policy outcomes (Cornwall 2008, Vatn and Vedeld 2013). Actors are unlikely to participate in events in which they have the experience of being silenced by more powerful voices or have reason to fear reprisals (Cornwall 2008). The level of an actor's autonomy to advocate his interests will drive his participation in decision making (Dalby 2005, Bifulco 2013), and the level of autonomy is often determined by the type of political system, e.g., authoritarian, decentralized, or democratic. In Vietnam, actors have limited autonomy (WellsDang 2010) and citizens of authoritarian regimes are often compliant (Tilly and Tarrow 2006). Given the authoritarian regime in Vietnam, we hypothesized that nonstate actors were likely to be more interested in participating in political events that were not led by the government because they would have more autonomy to exert their opinions and influence. Furthermore, nonstate actors are more likely to advocate for policy options that differ from those proposed by the government.

(3) To what extent do the outcomes, e.g., regulation and strategy, of REDD+ policy events incorporate the preferences of policy actors? We assessed the effectiveness of the participation mechanism by analyzing stakeholders' evaluation of the policy outcomes (Berardo and Scholz 2010). The participation of actors differs between political events because of factors such as their political interest and the availability of resources, i.e., actors need to prioritize their activities based on their financial resources (Verba and Nie 1972, Court et al. 2006). Policy systems encompass multiple events in which a variety of actors are engaged and invest their resources and time to influence policy makers (Hirschi et al.
2005, Lyster 2011). Therefore, we assessed the participation of actors in three core REDD+ policy events in which policy actors made collective decisions related to REDD+.

REDD+ policy in Vietnam has developed as a result of the following three core policy events, all of which are still active: (1) the release of two national regulations, Decision No. 380 and Decree No. 99; (2) the establishment of the UN-REDD program in Vietnam; and (3) the creation of REDD+ subtechnical working groups.

Decision No. 380, issued in 2008, established conditions to support payment for forest environmental services (PFES) pilot projects in Lam Dong and Son La provinces. In 2010, Decree No. 99 was issued, mandating the implementation of PFES nationwide from 1 January 2011, making Vietnam the first country in Asia to initiate a nationwide PFES scheme. Decree No. 99 treats carbon sequestration as a forest environmental service. The goals of the PFES program in Vietnam are to improve forest quality and quantity, increase the forestry sector's contribution to the national economy, reduce the state's financial burden for forest protection and management, and improve social wellbeing.

In March 2009, the UN-REDD program policy board approved US\$4.4 million for Vietnam's national REDD+ program. With the final approval of the national program in September 2009, the country entered its readiness phase. Under the program, capacity building and readiness activities for REDD+ are underway and REDD+ pilot projects are being implemented in several provinces.

REDD+ subtechnical working groups were established in 2010 under the National REDD+ Steering Committee, through Decision No. 2614/QD-BNN-LN (Government of Vietnam 2009). These working groups support the development of the national REDD+ program by giving advice to the technical working group, improving coordination between pilot projects and local governments and sharing information across pilot projects and between local and national levels. At the time we collected the data, six subtechnical working groups were operating, i.e., governance; monitoring, reporting, and verification; finance; benefit sharing; private sector engagement; and local implementation.

\section{METHODS}

This research was completed as part of CIFOR's global comparative study on REDD+. The research is based on the methodological framework and policy network survey guidelines of component 1 of that study (Brockhaus and Di Gregorio 2012).

To assess the extent to which actors participate in the REDD+ policy process in Vietnam, the first step of data collection was to identify those policy actors or organizations that were part of the REDD+ policy domain, i.e., research question 1: who is involved in national REDD+ policy making, and what are their interests in participating in core political events? A list of core policy actors was developed based on a literature review and consultation with government agencies, and a panel of five experts was formed and invited to confirm these actors. In addition, a list of core national REDD+ policies was compiled with the assistance of the expert panel. 
Table 1. REDD+ policy actors by group (Government, Business sector, National NGOs and CSOs, Media, and International NGOs and donors) and their levels of interest; actor didn't participate/had no interest (No Part); moderate/strong/very strong interest (Strong), had very little/little interest (Little) in three core REDD+ policy events in Vietnam.

\begin{tabular}{|c|c|c|c|c|c|c|c|c|c|c|}
\hline \multirow{2}{*}{$\begin{array}{l}\text { Core Policy } \\
\text { Event } \\
\text { Level of interest }\end{array}$} & & \multicolumn{3}{|c|}{ Decision 380/Decree 99} & \multicolumn{3}{|c|}{ UN-REDD Program } & \multicolumn{3}{|c|}{ Subtechnical Working Group } \\
\hline & & $\begin{array}{l}\text { No } \\
\text { Part } \\
(\%) \\
\end{array}$ & $\begin{array}{c}\text { Strong } \\
(\%)\end{array}$ & $\begin{array}{c}\text { Little } \\
(\%)\end{array}$ & $\begin{array}{c}\text { No Part } \\
(\%)\end{array}$ & $\begin{array}{c}\text { Strong } \\
(\%)\end{array}$ & $\begin{array}{l}\text { Little } \\
(\%)\end{array}$ & $\begin{array}{l}\text { No } \\
\text { Part } \\
(\%) \\
\end{array}$ & $\begin{array}{c}\text { Strong } \\
(\%)\end{array}$ & $\begin{array}{l}\text { Little } \\
(\%)\end{array}$ \\
\hline \multirow[t]{5}{*}{ Actor Group } & Government & 7 & 86 & 7 & 27 & 53 & 20 & 20 & 67 & 13 \\
\hline & Business sector & 0 & 63 & 37 & 100 & 0 & 0 & 100 & 0 & 0 \\
\hline & $\begin{array}{l}\text { National NGOs } \\
\text { and CSOs }\end{array}$ & 0 & 75 & 25 & 0 & 50 & 50 & 0 & 100 & 0 \\
\hline & Media & 0 & 80 & 20 & 60 & 20 & 20 & 100 & 0 & 0 \\
\hline & $\begin{array}{l}\text { International } \\
\text { NGOs and } \\
\text { Donors }\end{array}$ & 8 & 88 & 4 & 25 & 54 & 21 & 8 & 92 & 0 \\
\hline
\end{tabular}

Data were collected over 17 months, from July 2011 to December 2012. Two sets of questionnaires were used: (1) a structured questionnaire that included questions about opinions on REDD+ issues and participation in key REDD+-related policy events; and (2) a semistructured interview that explored actors' perceptions of governance challenges for REDD+ implementation in Vietnam. Survey respondents were representatives of organizations that were part of the REDD+ policy domain $(n=$ $52)$.

In the structured questionnaire, actors were asked to indicate their interest in participating in REDD+ policy events, their perceived level of influence over the final policy outcomes, the nature of their participation in these events, e.g., formal meetings or lobbying, and their evaluation of the achievements of these core political events. Interviewees were organizational representatives who were either assigned by their organization or had some kind of leadership or senior role and were directly responsible for REDD+-related topics within these organizations, as confirmed by experts on the panel and in accordance with our own knowledge

Participation in the three core events was analyzed through the construction of a two-mode policy network featuring policy actors, i.e., first-mode nodes, and events, i.e., second-mode nodes, in which ties between nodes indicated participation in the event (Borgatti and Everett 1997). This was visualized using UCINet and Netdraw software and required qualitative interpretation (Batagelj and Mrvar 1997, Borgatti et al. 2002).

In the semistructured interviews, actors were asked to describe their organization's interest in REDD + , their perception of policy challenges and opportunities for REDD+ implementation in Vietnam, for an evaluation of the role, nature, and effectiveness of consultation processes, and their organization's policy assessment of REDD+ outcomes. All interviews were recorded and later transcribed for analysis. Transcripts were analyzed through a coding procedure to identify data patterns. A thematic analysis involved the identification of specific themes, e.g., major governance challenges for REDD+ and effectiveness of current REDD+ consultation mechanism, in the data, and a comparative analysis was conducted to compare the results for intra-actor and interactor groups.

\section{RESULTS}

REDD+ actors and their interest in core policy events

Fifty-two organizations were identified as part of the national REDD+ policy domain in Vietnam. For our purposes and for clearer presentation, we classified these policy actors into five categories: government agencies (15), business sector, e.g., hydropower plants, timber processing companies, construction companies, and tourism companies (8), national NGOs (4), international NGOs and donors (20), and media (5).

All stakeholders $(n=52,100 \%)$ claimed that they had an interest in at least one of the three core REDD+ policy events. Government agencies and international NGOs and donors expressed an interest in all three policy events, whereas the business sector was interested only in event 1, i.e., Decision No. 380/Decree No. 99 (Table 1) because the business sector is directly affected by the outcomes of this decree. For example, to comply with these regulations (Decree No. 99), tourism companies, water supply companies, and hydropower plants must pay a certain amount of their revenue for forest protection and rural development. In contrast, the business sector had no interest in event 2 , i.e., the UN-REDD program, or event 3 , i.e., the REDD subtechnical working groups. Business actors interviewed claimed that they were unaware of these events and had never been invited to participate. National NGOs had the strongest interest in event 3 because it provided a platform for a national policy dialogue between NGOs and donors, and government agencies. These NGOs perceived this event as a channel through which they could approach government agencies with the presence and support of donors.

As actor groups' levels of interest in the three events varied, so too did their participation (Fig. 1). More stakeholders (95\%) participated in event 1, i.e., Decision No. 380/Decree No. 99, than in the other two events. Furthermore, actors within the same groups presented different patterns of participation in events. We found that perceptions related to the expected gains from 
Fig. 1. The participation of organizations to the three events (the position of nodes is not important and is based on optimizing visualization).

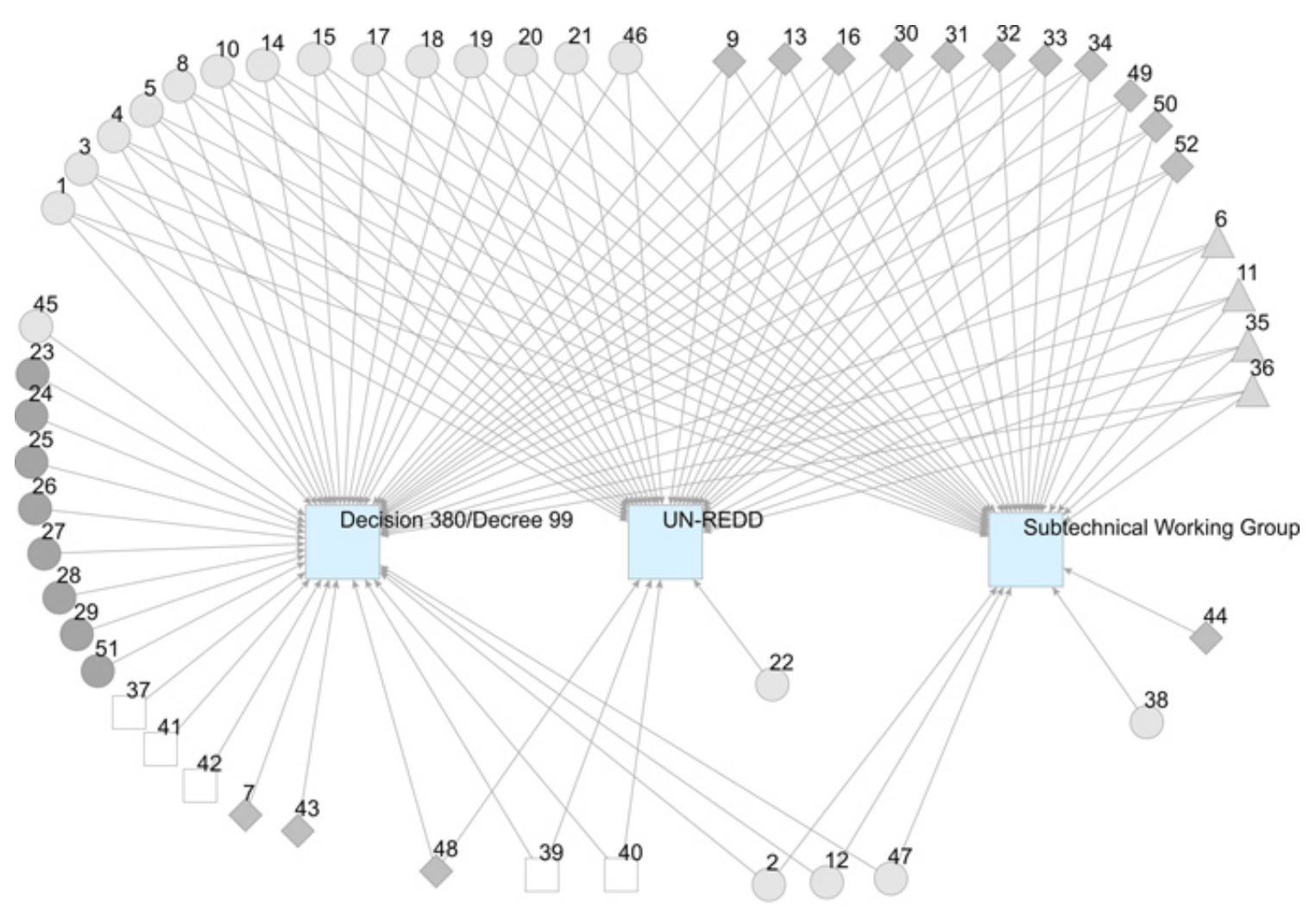

participation in an event, e.g., the Centre of Research and Development in Upland Areas wants to gain visibility and credibility in important meetings, whereas international NGOs want to introduce their research findings to influence decision making, affected the actors' level of interest, which was related to their participation. For example, not all government agencies were interested in the government-led event. The responses to the interviews show that the Ministry of Natural Resources and Environment (MONRE; Actor 044) had very little interest in event 1 and did not participate (Fig. 1). Our in-depth interviews with stakeholders revealed conflicts as well as weak cooperation between MONRE and the Ministry of Agriculture and Rural Development (MARD). Because MARD manages the forestry sector and forestlands, its development of the national PFES policy is seen as its territory, which leaves MONRE reluctant to get involved in related policy discussions. More importantly, some key ministries, most notably the Ministry of Planning and Investment and the Ministry of Finance, which are important for sectorial planning and financial management, did not participate in these events because they see REDD+ as outside their areas of expertise. Of all the ministries, only MARD is active in the REDD+ discussion. Furthermore, local government agencies have only limited representation in the current consultation process because most consultations are conducted at the national level and limited funding is available for local representatives to attend.
Although all actors participated in at least one event, only a subset of actors indicated that they were actively engaged in the decisionmaking processes in these events (Fig. 2). Fifteen percent of state actors $(\mathrm{n}=8)$, including Ho Chi Minh Provincial People's Committee (Actor 043) and Da Nhim Commune People's Committee (Actor 048), claimed that they had participated in the decision-making process of event 1 as observers only and that the decisions had been made by central state actors. Many international NGOs, such as World Wildlife Fund (WWF; Actor 046) and Winrock International (Actor 017), and donors, (Japan International Cooperation Agency; Actor 014; $n=14,27 \%$ ) also claimed that, despite their participation in all events, they were not involved in the decision-making process because of their limited political influence as well as their organizational mission to support the government in implementing policies rather than challenging it. Three business sector actors (5.8\%), namely Vietnam Electricity $(\mathrm{EVN})$, the largest, state-owned electricity monopoly (Actor 023), Son La Water supply company (Actor 028), and Dong Nai water company (Actor 029), claimed that they had been involved in decision making by offering alternative suggestions on the level of PFES payment level. However, other companies said they had not participated in the decision-making process largely because they did not think that they could influence the decisions. By contrast, some national NGOs, including the Centre of Research and Development in Upland Areas (Actor 006) and the Centre for Sustainable Rural 
Fig. 2. Participation in decision making of the three events (the position of nodes is not important and is based on optimizing visualization).

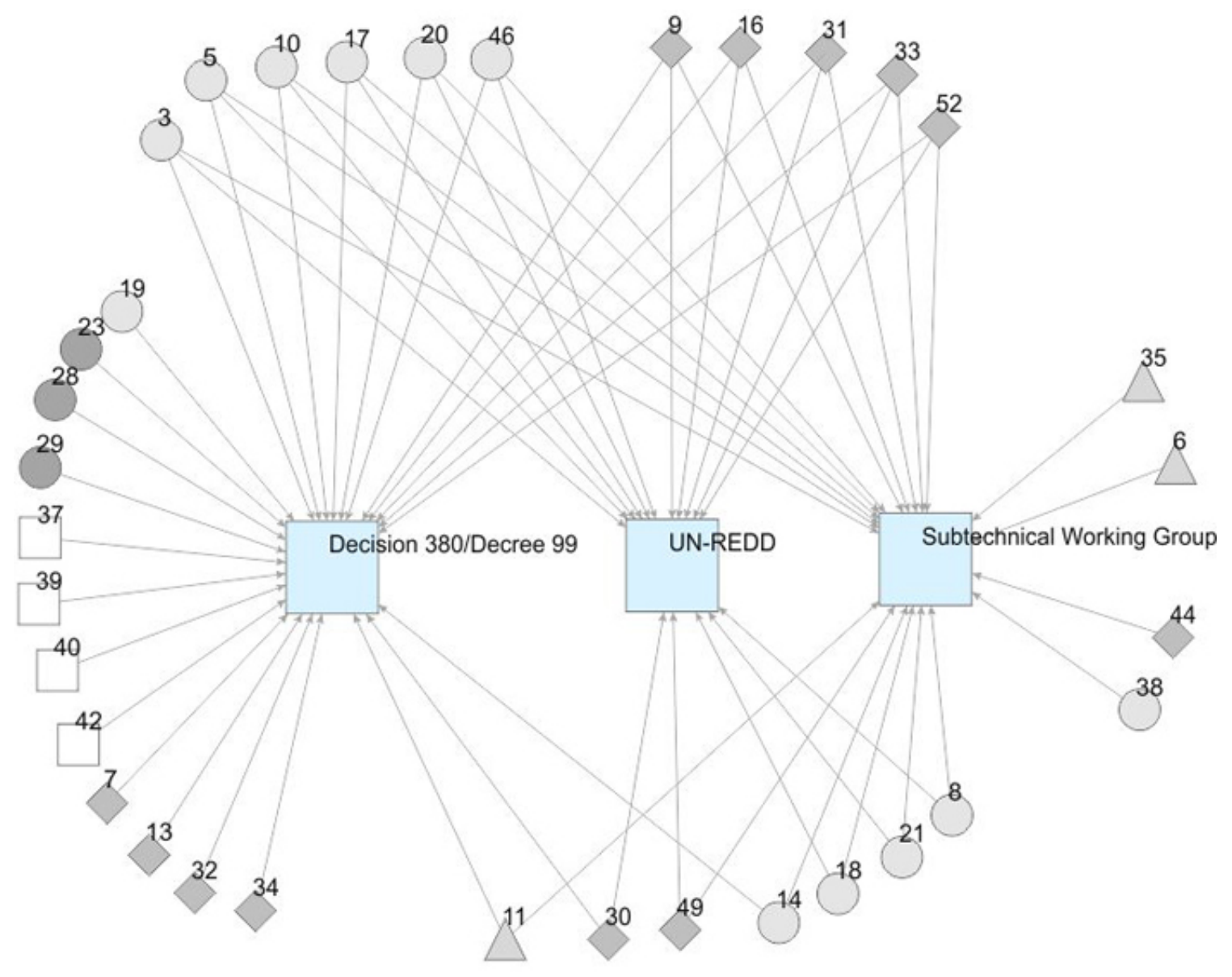

Development (SRD; Actor 035), claimed that they had been involved in decision making. According to the representatives of these organizations, they had contributed their experience in community-based forest management, which the central government had taken into account when designing REDD+.

\section{Level of participation in REDD+ policy events}

Of the three policy events, Decision No. 380/Decree No. 99 had the highest level of participation. It received the largest number of policy proposals from all stakeholders, including from government agencies themselves (Fig. 3), followed by the establishment of the subtechnical working groups, which had strong involvement of donors, state actors, and international NGOs.

Government agencies focused on proposing options for managing REDD+ financial contributions, which included merging the REDD+ fund into the state budget rather than allowing donors to establish an independent REDD+ fund outside state administration. By contrast, international donors called for an independent REDD+ fund operating outside the state administrative system to ensure financial transparency and accountability. National NGOs, on the other hand, proposed a multistakeholder-managed PFES/REDD+ trust fund with representation from all social actor groups to ensure that the PFES payment mechanism would be efficient, effective, and equitable. According to all government interviewees, consultations with businesses did have some impact on the final ruling in Decision No. 380 and Decree No. 99 concerning the level of PFES fees that businesses would be required to pay.

Government agencies were the only actors proposing alternatives in event 2. These related largely to where the UN-REDD pilot project should take place and what activities should be included. This pattern supports domestic nonstate actors in their assertion that the policy-making process is largely based on collaboration between donors and government agencies with the limited involvement of other actor groups. The establishment of the REDD+ subtechnical working group (event 3) attracted a much wider variety of actors, with alternative proposals coming from government agencies, donors, and national NGOs. Among these groups, national NGOs had the highest interest in the event and proposed numerous options for national REDD+ financial distribution and a benefit-sharing mechanism. Most of their 
Fig. 3. Results of the question "Thinking back to the beginning of this event, did your organization advocate an alternative policy?" posed to actors $(n=52)$ in the REDD+ policy arena in Vietnam. Results are given for each of three core REDD+ policy events and actors are organized into groups (Government, private sector, national NGOs and CSOs, International NGOs and donors).

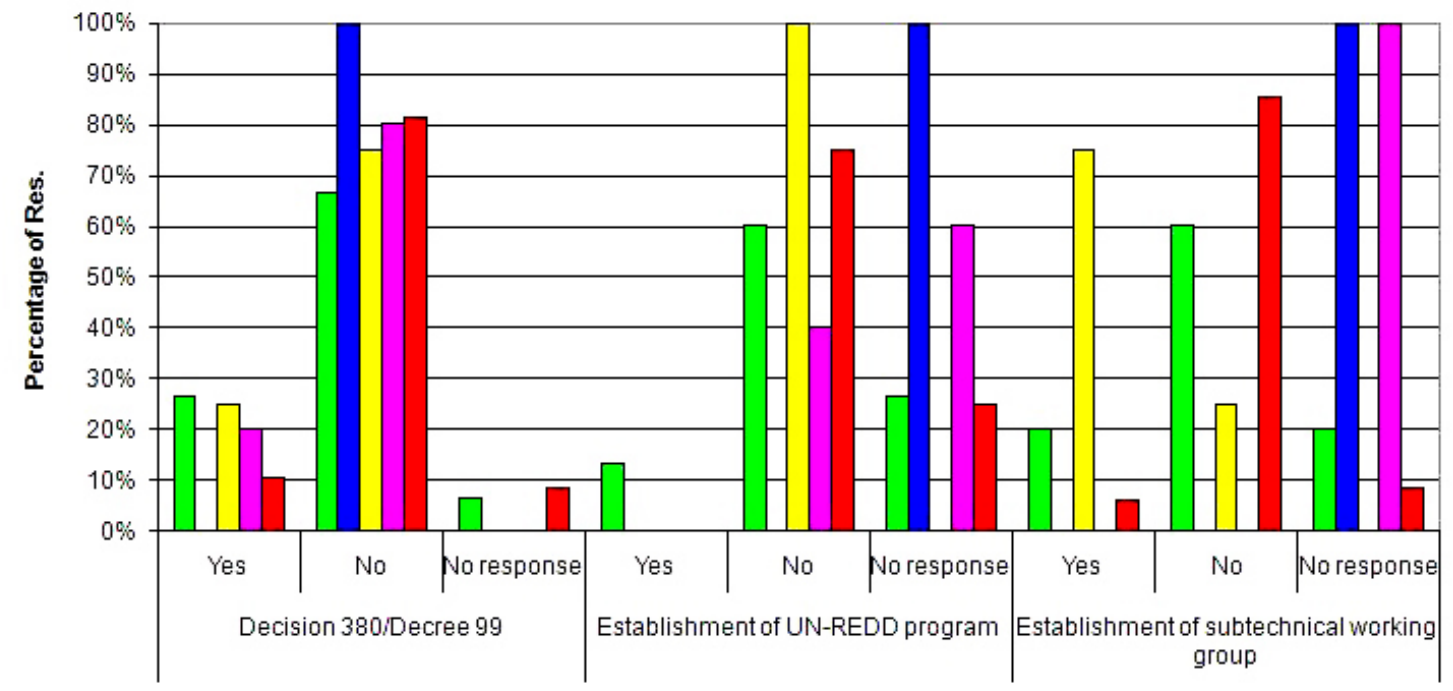

proposed options were propoor and based on their experience with community-based forest management. Two-thirds of the interviewees claimed that they only participated in this event to obtain updated information on the national REDD+ program and government and donors' priorities. All of the interviewees also noted that they had participated in these events to strengthen their networking and information exchange with other organizations.

\section{Incorporation of policy actors' preferences into REDD+ outcomes}

Most stakeholders (77\%) were skeptical about the effectiveness of the consultations and participatory approaches, which were employed in each of the three core policy events. Most stakeholders in Vietnam, however, felt that Decision No. 380/ Decree No. 99 had achieved at least some of their policy objectives, e.g., raising awareness of the role of forests and increasing the revenue of the forestry sector and its contribution to the national economy, but they saw events 2 and 3 as having achieved very few of their aims (Fig. 4).

However, international NGOs and donors, national NGOs, and businesses interviewed felt they had little influence during the formulation of Decree No.99. These interviewees claimed that Decision No. 380/Decree No. 99 were formed in top-down processes, led by central government agencies with support from scientists and donor communities and that no proper dialogues or consultations with business actors or local communities had taken place. International NGOs and donors generally agreed that Decree No. 99 was a positive policy but that it had not been able to address critical issues related to REDD+, including how carbon rights would be defined and formalized into law. Nearly two-thirds $(62 \%)$ of the international NGOs and donors and businesses interviewed questioned whether the policies would be effectively enforced and whether the money would reach the poor.

In event 2, 100\% $(\mathrm{n}=52)$ of the stakeholders interviewed highlighted the large number of consultation workshops and mailing lists that UN-REDD had used to disseminate information about the program and to seek actors' feedback on the design of UN-REDD's pilot program. One-third $(33 \% ; n=16)$ of actors interviewed also perceived these mechanisms as good ways to keep stakeholders up to date on the program's progress. In addition, $70 \%$ of actors felt that their participation and contributions were not reflected in the final decision. International and national NGOs interviewed were uncomfortable with the UN-REDD policy outcomes, mainly because of the high expectations about $\mathrm{REDD}+$ that the program had raised among local people and the ineffectiveness of the participatory approach the program adopted (50\% of NGOs and donors interviewed). All actors felt that UN-REDD had used consultation workshops as a way to engage stakeholders who were working on REDD+ in Vietnam, but that, as these workshops were often conducted in English, many actors could not participate because of the language barrier. Moreover, provincial and local representatives could not attend these consultation workshops because they did not have the resources to travel.

For event 3, 90\% of actors claimed that only NGOs and scientists actively participated and that government agency participation was minimal. All actors noted the absence of government representatives in subtechnical working group meetings and the 
Fig. 4. Results of the question "Given your organization's objectives in this event, would you say that ] were achieved?" posed to actors $(n=52)$ in the REDD+ policy arena in Vietnam. Results are given for each of the three core REDD+ policy events and actors are organized into groups (government, private sector, national NGOs and CSOs, and INGOs and donors). Responses of actors were organized as follows: all of its objectives (All, Most, About half, Few, None, and No responses).

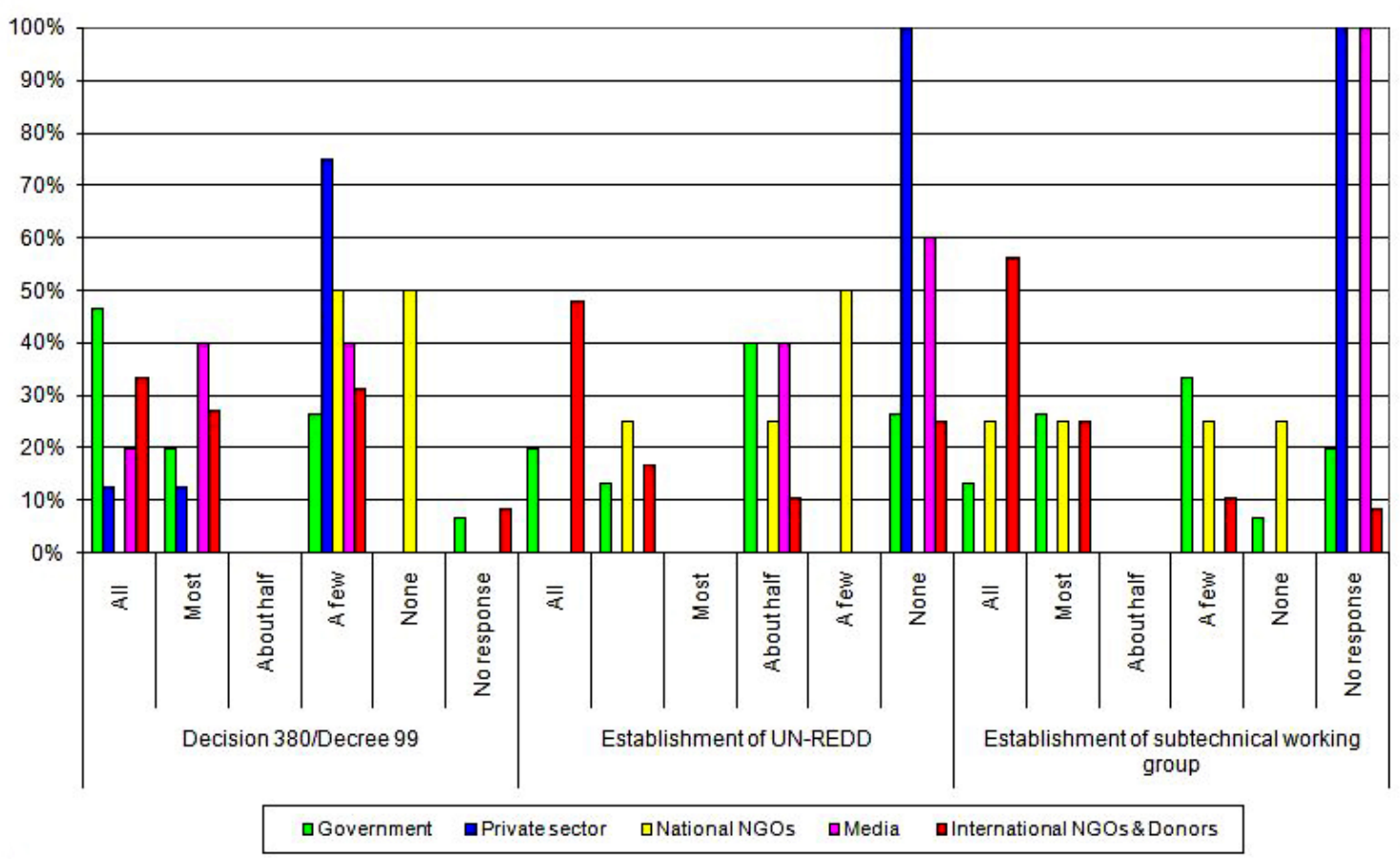

lack of feedback mechanisms to take discussion conclusions and proposals generated through these meetings to decision makers.

\section{DISCUSSION}

A range of policy actors are involved in the REDD+ policy arena in Vietnam. All of these actors had some involvement in at least one of the three main events shaping REDD+ policy, suggesting that the interests of different groups were presented and participation was good. For example, the inclusion of national NGOs in two of the three key policy events was a positive sign of the involvement of civil society in emerging international issues. Nevertheless, being involved in a process does not always lead to influence (VeneKlasen and Miller 2002, Cornwall 2008), nor to legitimacy of governance or accountability (Abels 2007, Biermann and Gupta 2011, Gupta et al. 2012). State actors remain the most powerful actor category; notably, MARD plays a major role in all three core policy events with nonstate actors having very limited influence. Different groups experienced a different quality of participation, and the voices and views of some groups were given greater weight than the voices of other groups (Edwards et al. 2000).

Our findings indicate that some important stakeholders were absent from all three events. First, those actors associated with major drivers of deforestation and forest degradation in Vietnam, including large-scale agriculture producers, e.g., the Vietnam Coffee and Tea Association, the Fishery Association, and large- scale timber and furniture companies, e.g., state forest enterprises (Pham et al. 2012), were not present in the debate. This is problematic for future REDD+ implementation in Vietnam because, without considering the interests of these groups, REDD+ policies will not be able to address these drivers effectively. Second, no representatives of vulnerable groups such as indigenous people and the poor were included in the consultation processes. National NGOs are expected to speak on behalf of these vulnerable groups. Interviewees attributed the absence of national NGOs to their limited political influence in Vietnam and only partly to their limited capacity and available resources. The issue, however, is not the absence of NGOs but rather the nonrepresentative nature of the processes. Moreover, some NGOs appear to favor donor interests because they rely on donors to fund their programs (Court et al. 2006, Pham et al. 2010).

Mass organizations, such as women's unions or farmers associations, are notably absent from REDD+ decision making. This should be seen not as the fault of Vietnamese civil society but rather as a structural feature of the political system: grassroots interests are meant to be represented via mass organizations but this does not often occur in practice.

Without the meaningful inclusion of those who will be affected by the outcomes of environmental decision making, distribution of environmental benefits is unlikely to be fair (Amerasinghe et 
al. 2008). However, despite the emphasis on developing inclusive processes, which ensure that particular groups are included, relatively little attention has been directed to 'self-exclusion,' i.e., the active choice 'not' to participate, (Cornwall 2008). Nonparticipation does not always mean having been excluded (Hayward et al. 2004, Shortall 2008). Cornwall (2008) argued that actors might choose not to participate in decision making for several reasons, including not having a sense of belonging to a community. Actors can exclude themselves from the process because the spaces in which meetings and other participatory events take place are culturally associated with groups to which they do not belong or activities with which they are unfamiliar or uncomfortable (Cornwall 2008). This perhaps explains the fact that MONRE excluded itself from national REDD+ policy making. Second, self-exclusion can be associated with a lack of confidence and a feeling that one does not have much to contribute (Hayward et al. 2004). This explains the absence of the Ministry of Finance and the Ministry of Planning and Investment as most of these organizations' interviewees claimed they did not have sufficient knowledge about REDD+ to participate; hence, they participated in core policy events as observers only.

Consultation meetings, as a tool to fulfill the requirements of participation, seemed largely ineffective and inadequate for incorporating the suggestions and opinions of international NGOs and for generating serious feedback. According to most interviewees, both governments and donors have adopted participatory governance processes primarily to comply with international requirements. This weak motivation may be contributing to the ineffectiveness of consultations, which provide little incentive for stakeholders to maintain their engagement in the political process. Others have argued that participation cannot be achieved by simply convening participatory workshops (Cornwall 2008). Rather, effective participation depends on how policy makers make use of what information is offered them as well as how well processes can help build capacity, nurture voice, and enable people to empower themselves (Cornwall 2008). This would require the government to exhibit strong political will in converting its professed commitment to participation into tangible action and in applying strategies to build and support collective action (Houtzager and Pattenden 1999).

More importantly, even when an organization may not have a tangible impact on policy, it might still benefit from participation in the policy process because this participation could stimulate future dialogue and provide the organization with public visibility and credibility. Most of the national NGO interviewees said that participation in policy events helped them to gain better access to donor funding and strengthened their networks with other NGOs. They also felt that they had learned about international REDD+ events through dialogue with the international organizations that participated in these events.

We found that, contrary to our expectations, the government-led policy event, i.e., Decision No. 380/Decree No. 99, did not receive the least alternative policy proposals. A possible explanation is that participation and engagement in policy making tend to be time consuming and costly for policy actors. Therefore, actors must be strategic when deciding where to invest their resources by carefully choosing which policy events to participate in, i.e., selecting those from which they can derive the greatest benefit
(Court et al. 2006). Most interviewees claimed that they saw more value in engaging in government-led events, which tried to influence new policies, than in donor-led events, which aimed to improve donors' project design. Furthermore, all actors interviewed indicated that they actively engaged in event 2 initially, but their interest and participation had waned by the time of the survey because of mistrust in and disappointment with the consultation process. This is what Cornwall (2008) called 'consultation fatigue,' which arises when participatory processes are of poor quality and little impact on actual policy decisions is seen. Third, the more directly actors are affected by a policy, the more actively they participate in decision making. This phenomenon is well illustrated in the case of the business sector and its participation in event 1 , whereas businesses stayed away from the other two events because they were unlikely to have any impact on their interests.

Our findings are similar to those of Wells-Dang (2010) in that, although authoritarian states such as Vietnam are often characterized as having 'closed' political opportunity structures and 'un-free' socio-political systems, the political structures do provide some political space for nonstate actors. This is explained by two factors. First, political space in Vietnam is not fully limited by the state nor always formally constituted in recognizable institutions. When we looked at what actors said in terms of how much the policy events had achieved, we noted that the majority of responses from the business sector claimed that 'few objectives' had been achieved, which suggests that there was a compromise between state and business. Several international NGOs noted that the process of consultation and REDD+ policy development in Vietnam is much better than it was 30 years ago. For example, at that time, Vietnam had no NGOs and the present government has produced policies representing, at the very least, a call for a more participatory and transparent information exchange, e.g., the national REDD+ program. Second, although Vietnam has no opposition parties, nonstate actors can still engage in political discussion even though they are not seen as powerful because of their active efforts to contend with government policies (O'Brien and $\mathrm{Li}$ 2006). Existing approaches for measuring political space offer little insight that can explain the political dynamics in Vietnam (Wells-Dang 2005). Numerous scholars have analyzed and compared country governance using indicators such as 'open' or 'closed,' 'democratic,' or 'not free' (Tilly and Tarrow 2006), but such indicators might not always explain the complexities of politics in any particular society (Wells-Dang 2010). Political analysts, therefore, need to focus not only on the immediate impact of current events, but also on the cumulative long-term trends and processes that build over time.

\section{CONCLUSION}

Our findings show that Vietnam is on its way to developing a national REDD+ policy with political commitment and effort from the government. The variety of stakeholders involved in REDD+ and their strong interest in REDD+ can lead to a wide range of policy proposals, which could potentially offer a wide selection of options for REDD+ implementation. However, in the current political context, the dominance of government agencies and donors combined with the lack of representation of grassroots actors threatens REDD+ and its ability to engage multiple actors in decision making. The study also shows that the REDD+ decision-making process in Vietnam is weakened not 
only by its inability to address the interests and concerns of those who participate in the formal arena, but also by its inability to involve and engage important actors who are drivers of deforestation and forest degradation. That being said, the study also shows positive signs of decision making in which actors have the political space to propose alternative policy options, even in highly centralized policy events. Ensuring accountability and inclusive decision making in Vietnam, as elsewhere, will require a considerable shift from the current governance system of topdown and command approaches to a more participatory approach.

Responses to this article can be read online at: http://www.ecologyandsociety.org/issues/responses. php/6389

\begin{abstract}
Acknowledgments:
This research is part of the policy component of CIFOR's Global Comparative Study on REDD+ (www.forestsclimatechange.org/ global-comparative-study-on-redd.html). The methods applied build partially on research undertaken by the Comparing Climate Change Policy Networks program (http://compon.org), which is funded by the National Science Foundation. We would like to thank Christine Wairata, Sofi Mardiah, Efrian Muharrom, and CIFOR's communication team, who played highly valuable roles in research support and editing. Funding for CIFOR's research was provided by the Norwegian Agency for Development Cooperation, the Australian Agency for International Development, the UK Department for International Development, and the European Commission.
\end{abstract}

\section{LITERATURE CITED}

Abels, G. 2007. Citizen involvement in public policy-making: does it improve democratic legitimacy and accountability? The case of pTA. Interdisciplinary Information Sciences 13(1):103-116.

Amerasinghe, M., L. Farrell, S. Jin, N. Shin, and K. Stelljes. 2008. Enabling environmental justice: assessment of participatory tools. Massachusetts Institute of Technology, Cambridge, Massachusetts, USA. [online] URL: http://web.mit.edu/jcarmin/www/carmin/ EnablingEJ.pdf

Angelsen, A., editor. 2008. Moving ahead with REDD: issues, options and implications. Center for International Forestry Research (CIFOR), Bogor, Indonesia. [online] URL: http://www. cifor.org/publications/pdf files/Books/BAngelsen0801.pdf

Arnstein, S. R. 1969. A ladder of citizen participation. Journal of the American Institute of Planners. 35(4):216-224. http://dx.doi. org/10.1080/01944366908977225

Batagelj, V., and A. Mrvar. 1997. Pajek: program for large network analysis. University of Ljubljana, Ljubljana, Slovenia. [online] URL: http://pajek.imfm.si/doku.php?id=pajek

Berardo, R., and T. J. Scholz. 2010. Self-organizing policy networks: risk, partner selection, and cooperation in estuaries. American Journal of Political Science 54(3):632-649. http://dx.doi. org/10.1111/j.1540-5907.2010.00451.x
Biermann, F., and A. Gupta. 2011. Accountability and legitimacy in earth system governance: a research framework. Ecological Economics 70(11):1856-1864. http://dx.doi.org/10.1016/j. ecolecon.2011.04.008

Bifulco, L. 2013. Citizen participation, agency and voice. European Journal of Social Theory 16(2):174-187. http://dx.doi. org/10.1177/1368431012459695

Black-Hawkins, K. 2010. The framework for participation: a research tool for exploring the relationship between achievement and inclusion in schools. International Journal of Research and Method in Education 33(1):21-40. http://dx.doi.org/10.1080/174$\underline{37271003597907}$

Borgatti, S. P., and M. G. Everett. 1997. Network analysis of 2mode data. Social Networks 19:243-269. http://dx.doi. org/10.1016/S0378-8733(96)00301-2

Borgatti, S. P., M. G. Everett, and L. C. Freeman. 2002. UCINet for Windows: software for social network analysis. Analytic Technologies, Cambridge, Massachusetts, USA.

Bourgoin, J., J.-C. Castella, C. Hett, G. Lestrelin, and A. Heinimann. 2013. Engaging local communities in low emissions land-use planning: a case study from Laos. Ecology and Society 18(2): 9. http://dx.doi.org/10.5751/ES-05362-180209

Brechin, S. R., P. R. Wilshusen, C. L. Fortwangler, and P. C. West, editors. 2003. Contested nature: promoting international biodiversity with social justice in the twenty-first century. State University of New York Press, Albany, New York, USA.

Brockhaus, M., and M. Di Gregorio. 2012. A brief overview: component 1 on national REDD+ policies and processes. InfoBrief No. 13. Center for International Forestry Research (CIFOR), Bogor, Indonesia. [online] URL: http://www.cifor.org/publications/ pdf files/infobrief/3858-infobrief.pdf

Chaskin, R., A. Khare, and M. Joseph. 2012. Participation, deliberation and decision making: the dynamics of inclusion and exclusion in mixed income developments. Urban Affairs Review 48(6):863-906. http://dx.doi.org/10.1177/1078087412450151

Chhatre, A., S. Lakhanpal, A. M. Larson, F. Nelson, H. Ojha, and J. Rao. 2012. Social safeguards and co-benefits in REDD+: a review of the adjacent possible. Current Opinion in Environmental Sustainability 4(6):654-660. http://dx.doi.org/10.1016/ j.cosust.2012.08.006

Corbera, E., and H. Schroeder. 2011. Governing and implementing REDD+. Environmental Science and Policy 14:89-99. http://dx.doi.org/10.1016/j.envsci.2010.11.002

Cornwall, A. 2008. Unpacking 'participation': models, meanings and practices. Community Development Journal 43(3):269-283. http://dx.doi.org/10.1093/cdj/bsn010

Court, J., E. Mendizabal, D. Osborne, and J. Young. 2006. Policy engagement: how civil society can be more effective. Overseas Development Institute, London, UK. [online] URL: http://www. odi.org.uk/sites/odi.org.uk/files/odi-assets/publications-opinionfiles/200.pdf

Dalby, S. 2005. Political space: autonomy, liberalism, and empire. Alternatives 30(4):415-441. http://dx.doi.org/10.1177/030437540503000402 
de Jong, W., D. S. Do, and V. H. Trieu. 2006. Forest rehabilitation in Vietnam: histories, realities and future. Center for International Forestry Research (CIFOR), Bogor, Indonesia. [online] URL: http://www.cifor.org/publications/pdf_files/Books/BDeJong0601. pdf

Edwards, R. W., P. Jumper-Thurman, B. A. Plested, E. R. Oetting, and L. Swanson. 2000. Community readiness: research to practice. Journal of Community Psychology 28(3):291-307. http:// dx.doi.org/10.1002/(SICI)1520-6629(200005)28:3<291::AID-JCOP5>3.3. $\underline{\mathrm{CO} ; 2-0}$

Fiorina, M. P. 1999. Extreme voices: a dark side of civic engagement. Pages 395-425 in T. Skocpol and M. P. Fiorina, editors. Civic engagement in American democracy. Brookings Institution, Washington, D.C., USA. [online] URL: http://www. stanford.edu/ mfiorina/Fiorina $\% 20$ Web $\% 20$ Files/DarkSide.pdf

Government of Vietnam. 2009. Decision 2614/QD-BNN-LN: establishment of the national network and working group for reducing emissions from deforestation and degradation (REDD). Government of Vietnam, Hanoi, Vietnam. [online] URL: http:// vietnam-redd.org/Upload/Download/File/Decision_for_establishment of REDD Network EN 5526.pdf

Government of Vietnam. 2012. Decision 779/Q $\ddot{A}-T T g$ dated on 27 June 2012 on national action plan for emission reduction through reducing deforestation, forest degradation, sustainable management of forest resources, conservation and improvement of forest carbon stock period 2011-2020. Government of Vietnam, Hanoi, Vietnam. [online] URL: http://www.vietnam-redd.org/Upload/ Download/File/799-QD-TTg_En_3104.pdf

Groom, B., and C. Palmer. 2012. REDD+ and rural livelihoods. Biological Conservation 154:42-52. http://dx.doi.org/10.1016/j. biocon.2012.03.002

Gupta, A., E. Lövbrand, E. Turnhout, and M. J. Vijge. 2012. In pursuit of carbon accountability: the politics of REDD+ measuring, reporting and verification systems. Current Opinion in Environmental Sustainability 4(6):726-731. http://dx.doi. org/10.1016/j.cosust.2012.10.004

Hampton, G. 2004. Enhancing public participation through narrative analysis. Policy Sciences 37(3-4):261-276. http://dx.doi. org/10.1007/s11077-005-1763-1

Hayes, T., and L. Persha. 2010. Nesting local forestry initiatives: revisiting community forest management in a REDD+ world. Forest Policy and Economics 12:545-553. http://dx.doi. org/10.1016/j.forpol.2010.07.003

Hayward, C., L. Simpson, and L. Wood. 2004. Still left out in the cold: problematising participatory research and development. Sociologia Ruralis 44(1):95-108. http://dx.doi.org/10.1111/ j.1467-9523.2004.00264.x

Hirschi, C., U. Serdült, C. Vögeli, and T. Widmer. 2005. The ActorProcess-Event Scheme (APES): issues of validity and reliability for network applications. Second Conference on Applications of Social Network Analysis, 20-21 October 2005. Zurich, Switzerland. [online] URL: http://www.apes-tool.ch/assets/files/ paper_Zurich.pdf

Houtzager, P. P., and J. Pattenden. 1999. Finding the shape of the mountain: when "the poor" set the agenda. Workshop on Political
Systems and Poverty Alleviation 16-17 August 1999, Castle Donnington, UK. Governance Division of the UK Department for International Development (DFID), East Kilbride, UK.

Larson, A. M. 2011. Forest tenure reform in the age of climate change: lessons for REDD+. Global Environmental Change 21:540-549. http://dx.doi.org/10.1016/j.gloenvcha.2010.11.008

Lederer, M. 2011. From CDM to REDD+: what do we know for setting up effective and legitimate carbon governance? Ecological Economics 70:1900-1907. http://dx.doi.org/10.1016/j.ecolecon.2011.02.003

Lyster, R. 2011. REDD+, transparency, participation and resource rights: the role of law. Environmental Science and Policy 14:118-126. http://dx.doi.org/10.1016/j.envsci.2010.11.008

Marochi, B. 2010. Political inclusion and representative claim making in participatory governance: case studies from Birmingham and Copenhagen. Dissertation. Roskilde University, Roskilde, Denmark. [online] URL: http://rudar.ruc.dk//bitstream/1800/6346/4/ BelisaThesisFinal2March.pdf

McDermott, C. L., L. Coad, A. Helfgott, and H. Schroeder. 2012. Operationalizing social safeguards in REDD+: actors, interests and ideas. Environmental Science and Policy 21:63-72. http://dx. doi.org/10.1016/j.envsci.2012.02.007

Murphy, D. 2011. Safeguards and multiple benefits in a REDD+ mechanism. International Institute for Sustainable Development (IISD), Winnipeg, Manitoba, Canada. [online] URL: http://www. iisd.org/pdf/2011/redd_safeguards.pdf

Mustalahti, I., A. Bolin, E. Boyd, and J. Paavola. 2012. Can REDD+ reconcile local priorities and needs with global mitigation benefits? Lessons from Angai Forest, Tanzania. Ecology and Society 17(1): 16. http://dx.doi.org/10.5751/ ES-04498-170116

O'Brien, K. J., and L. Li. 2006. Rightful resistance in rural China. Cambridge University Press, Cambridge, UK.

Pham, T. T., B. M. Campbell, S. Garnet, H. Aslin, and M. H. Hoang. 2010. Importance and impacts of intermediary boundary organisations in facilitating payment for environmental services in Vietnam. Environmental Conservation 37(1):64-72. http://dx. doi.org/10.1017/S037689291000024X

Pham, T. T., M. M. Moeliono, T. H. Nguyen, H. T. Nguyen, and T. H. Vu. 2012. The context of REDD+ in Vietnam: drivers, agents, and institutions. Center for International Forestry Research (CIFOR), Bogor, Indonesia. [online] URL: http://www.cifor.org/ publications/pdf files/OccPapers/OP-75.pdf

Phelps, J., M. C. Guerrero, D. A. Dalabajan, B. Young, and E. L. Webb. 2010. What makes a 'REDD' country? Global Environmental Change 20(2):322-332. http://dx.doi.org/10.1016/ j.gloenvcha.2010.01.002

Phillips, A. 1995. The politics of presence. Clarendon, Oxford, UK. http://dx.doi.org/10.1093/0198294158.001.0001

Pretty, J. N. 1995. Participatory learning for sustainable agriculture. World Development 23(8):1247-1263. http://dx.doi. org/10.1016/0305-750X(95)00046-F

Quick, S. K., and S. M. Feldman. 2011. Distinguishing participation and inclusion. Journal of Planning Education and Research 31(3):271-290. http://dx.doi.org/10.1177/0739456X11410979 
Raik, D. B., and D. J. Decker. 2007. A multisector framework for assessing community-based forest management: lessons from Madagascar. Ecology and Society 12(1): 14. [online] URL: http:// www.ecologyandsociety.org/vol12/iss1/art14/

Shortall, S. 2008. Are rural development programmes socially inclusive? Social inclusion, civic engagement, participation, and social capital: exploring the differences. Journal of Rural Studies 24(4):450-457. http://dx.doi.org/10.1016/j.jrurstud.2008.01.001

Sikor, T. 2010. REDD-plus, forest people's rights and nested climate governance. Global Environmental Change 20(3):423-425. http://dx.doi.org/10.1016/j.gloenvcha.2010.04.007

Stringer, L. C., A. J. Dougill, E. Fraser, K. Hubacek, C. Prell, and M. S. Reed. 2006. Unpacking 'participation' in the adaptive management of social-ecological systems: a critical review. Ecology and Society 11(2): 39. [online] URL: http://www. ecologyandsociety.org/vol11/iss2/art39/

Thompson, M. C., M. Baruah, and E. R. Carr. 2011. Seeing REDD+ as a project of environmental governance. Environmental Science and Policy 14:100-110. http://dx.doi. org/10.1016/j.envsci.2010.11.006

Tilly, C., and S. Tarrow. 2006. Contentious politics. Oxford University Press, Oxford, UK.

United Nations Framework Convention on Climate Change (UNFCCC). 2010. The Cancun agreements: outcome of the work of the ad Hoc working group on long-term cooperative action under the Convention, decision 1/CP 16, UNFCCC/CP/2010/7/ add.1. Report of the Conference of the parties on its sixteenth session. November 29 - December 10, 2010. Cancun, Mexico. United Nations Framework on Climate Change, Bonn, Germany. [online] URL: http://unfccc.int/resource/docs/2010/cop16/eng/07a01. pdf
Vatn, A., and O. P. Vedeld. 2013. National governance structures for REDD+. Global Environmental Change 23(2):422-432. http:// dx.doi.org/10.1016/j.gloenvcha.2012.11.005

VeneKlasen, L., and V. Miller. 2002. A new wave of power, people and politics: the action guide for advocacy and citizen participation. Practical Action, Warwickshire, UK.

Verba, S., and N. H. Nie. 1972. Participation in America: social equality and political democracy. Harper and Row, New York, New York, USA.

Visseren-Hamakers, I. J., C. McDermott, M. J. Vijge, and B. Cashore. 2012. Trade-offs, co-benefits and safeguards: current debates on the breadth of REDD+. Current Opinion in Environmental Sustainability 4(6):646-653. http://dx.doi.org/10.1016/ j.cosust.2012.10.005

Wells-Dang, A. 2010. Political space in Vietnam: a view from the 'rice-roots.' Pacific Review 23(1):93-112. http://dx.doi. org/10.1080/09512740903398355

Wells-Dang, A. 2005. Migrant workers in Vietnam's industrial zones. Action Aid, Hanoi, Vietnam.

White, S. C. 1996. Depoliticising development: the uses and abuses of participation. Development in Practice 6(1):6-15. http://dx.doi. org/10.1080/0961452961000157564 